\title{
Orientation and Decision Making Styles: The Case of Vietnamese Customers' Purchase of Audiovisual Products
}

\author{
Dao Tung* \\ VNU International School, Building G7-G8, 144 Xuan Thuy, Cau Giay, Hanoi, Vietnam
}

Received 05 April 2017

Revised 11 June 2017, Accepted 28 June 2017

\begin{abstract}
This research aims to investigate the relationship between time orientation (past, future, and present orientation) and the decision making styles of Vietnamese customers when they decide to purchase a audiovisual product. A survey was conducted on 423 Vietnamese customers in Hanoi in 2016. The results demonstrate significant relationships between perspectives of time orientation and customer's decision-making styles. Among the three time perspectives, the past and future orientation manifest a significant difference between decision making styles (customer segments). The present orientation was shown to have significant relationships with some individual characteristics of decision-making styles, but no significant difference found between decision-making styles.
\end{abstract}

Keywords: Time Orientation, Decision Making Styles (DMS), Vietnamese Customers, Audiovisual products.

\section{Introdution}

In recent decades, the relationship between time orientation and customer behavior has attracted considerable attention from scholars. More specifically, prior researches indicate that time orientation is an important psychological characteristic that can have significant impact on the cognition and behaviors of customers [1-4].

Despite of the significant number of studies on the impact of time orientation on customer behavior, no reseach so far addresses the relationship between time orientation and customer's decision making styles (DMS). Hence, this research is conducted with the hope to fill this niche. The Sproles and Kendall's approach of investigating DMS [5] will be

\footnotetext{
*Tel.: 84-913321996.

Email: tungd@isvnu.vn

https://doi.org/10.25073/2588-1116/vnupam.4089
}

applied in this study because it has high practical implications and allows us to understand customer's decision making styles based on their fundamental characteristics which are related to purchasing decisions. Additionally, this research explores the decisions to purchase audiovisual products which are considered to be expensive and durable goods and are suitable to the research objective of exploring the effects of customer's time orientation on customer's decision making styles.

\section{Literature review}

\subsection{Time orientation concept}

Lewin [6] defined time orientation as "the totality of the individual's views of his/her psychological future and psychological past existing at a given point of time" (p. 75). Each 
individual or customer has his/her own view and awareness on past, present, and future. In other words, the way each person perceives and considers how past, present and future is important varies among invidivuals [3].

Time orientation is regarded as a dimension of personality of customers. On the one hand, prior research shows that customers' time orientation is influenced by various factors such as culture, religion, income and experience [7], age, and social class [8]. Previous studies also indicate that time orientation can have an impact on the awareness and actions of customers [1], consumer innovativeness [2, 3] and consumers' shopping behaviors [4]. According to Merchant, Rose and Rose [3], how a customer evaluates and decides to buy a product depends on how he/she considers the benefits of the product in the past, present, and future. In short, time orientation can affect many behaviors of customers including the decision to purchase.

In the next paragraphs, more details will be explained on the main characteristics of past-, future-, and present-orientation customers and how these perspectives of time orientation can influence their behaviors.

First, past orientation is the tendency and habit to think about the past and connect actions and life in the present with events and emotions in the past [6]. The concept of "nostalgia" is normally used to describe this "past-time orientation". Past oriented people are suggested to search for events or things that they already experienced in the past, or are connected with their past. Hence, they can have a calm feeling at present (because they feel that events at the present are familiar and closed to what they already experienced) [9]. However, as a result, they do not show much care about new changes and new products [2].

Second, future orientation is the tendency to consider future events more important than present or past events [10]. According to Lens and Gally [11], future orientation plays a vital role in determining the awareness and behaviors of customers. It provides customers motivations, targets and the activeness in gathering resources and turns their thoughts into actions. The stronger the future orientation is, the more significantly it can influence people's actions in present.

Third, present orientation, according to Agarwal and Tripathi [10], is the preferences of individuals on what is happening at the present to what is going to happen in the future or what already happened in the past. Some of the most notable characteristics of present oriented people include being inactive in solving their own tasks, usually waiting for things to happen (instead of preparing in advance), not being interested in changes, tending to simplify life, and hardly spend efforts on solving their tasks (while expecting for support from others) [12]. Present orientation also relates to unplaned decisions to purchase products and actions based on emotions [13].

\subsection{Decision-making styles concept}

A consumer's decision making style (DMS) is defined by Sproles [14] as "a patterned, mental, and cognitive orientation towards shopping and purchasing, which constantly dominates the consumer's choices resulting in a relatively-enduring consumer personality", or "a mental orientation characterizing a consumers' approach to making choices" [5]. In addition, customer's DMS has cognitive and affective characteristics (for example the quality consciousness and the design or fashion consciousness) and is regarded as a basic consumer personality.

In the literature on consumer behavior, different purchasing DMS have been identified. The studied DMS relates to different steps in the customer's decision making process. Research on DMS can be classified into four main categories: information gathering and processing styles $[15,16]$, styles related to the evaluation and selection of alternatives [17, 18], shopping orientation or shopping styles [19, 20], and DMS based on the fundamental characteristics of purchasing decisions (such as price, quality or brand consciousness [5, 14]. 
Beside these, some research investigated the purchasing DMS in some specific contexts, for example, organization's buying styles $[21,22]$ or DMS in the purchasing of medical services or insurance [23].

Sproles and Kendall [5] identified eight fundamental characteristics of customer's decision making styles, including Perfectionism, High quality Consciousness; Brand Consciousness; Novelty-Fashion Consciousness; Recreational Shopping Consciousness; Price-Value Consciousness, Impulsiveness; Confused by Over choice; and Brand-Loyal/Habitual Shopping Consciousness. The authors also indicated that in reality there are other characteristics that can be used to characterize customer decision making style, but the characteristics chosen are among the most fundamental and most discussed in the literature.

When purchasing products, each customer uses a specific combination of these fundamental characteristics to make his/her choice. The specific combination of fundamental characteristics forms the customer's decision making style. This appears stable but may vary in some extent depending on the kind of product or purchasing situations [14]. Sproles and Kendall [4] state that "...we cannot assume that a consumer with high brand consciousness would consider "name" products on every decision" and "... consumer may have different comsumer styles for each product category" (p. 276). The segmentation of customers based on the fundamental characteristics should be one of the important techniques to qualify customer's DMS as a specific combination of fundamental caracteristics.

By applying this approach to investigate the customer's decision making style in case of audiovisual product, Dao and Jallais [24] identified six fundamental characteristics of Vietnamese customers including Brand Consciousness, Guaranty Consciousness, Design Consciousness, Perfection and Best Quality Consciousness, Price Consciousness, and Confusion. The clustering of customers based on these characteristics identified four segments or four decision making styles that are named Relativist Customers, Price Consciousness Customers, Confused Customers, and Luxury and Safe Customers.

\section{Methodology}

\subsection{Research methods}

The research attempts to reveal the impact of time orientation on decision making style at two levels: characteristics level and DMS level (combination of characteristics). At the characteristics level, a Pearson correlation analysis will be used to determine if there is a relationship between time orientation perspectives and DMS characteristics. Next, a comparison of mean score of customers' time orientation between different segments of customers, i.e. DMSs, issued by a classification of customers, will be carried out. The existence of a significant difference of the mean score of time orientation between segments states a significant relationship between decisionmaking styles and customers' time orientation, and inversely. The One-way ANOVA will be used for mean comparison analysis, and the hierarchical classification with Ward's method will be applied to segment customers using purchasing fundamental caracteristics in order to identify homogenous groups of customer or DMSs.

\subsection{Measurement of variables}

The measure of the perspectives of time orientation (Past, Present, and Future orientation) consists of 9-item scale used by Dao [25]. The items were translated into Vietnamese by experienced experts in English language, and checked with a small group of Vietnamese customers to ensure good understanding on the meaning of the items.

The measure of decision making styles includes 20-item scale, adapted from Sproles and 
Table 2. Measurement Scale of DMS Characteristics

\begin{tabular}{|c|c|c|c|c|c|c|}
\hline & $\begin{array}{l}\text { Guarantee } \\
\text { Consciousness }\end{array}$ & $\begin{array}{l}\text { Perfection/ } \\
\text { Best quality } \\
\text { Consciousness }\end{array}$ & Confusion & $\begin{array}{l}\text { Price } \\
\text { Advantage } \\
\text { Consciousness }\end{array}$ & $\begin{array}{l}\text { Design } \\
\text { Consciousness }\end{array}$ & $\begin{array}{l}\text { Brand } \\
\text { reputation } \\
\text { Consciousness }\end{array}$ \\
\hline GUAR3 & $.83(.72)$ & & & & & \\
\hline GUAR1 & $.82(.77)$ & & & & & \\
\hline GUAR2 & $.78(.75)$ & & & & & \\
\hline PERF2 & & $.84(.75)$ & & & & \\
\hline PERF3 & & $.80(.75)$ & & & & \\
\hline PERF1 & & $.76(.58)$ & & & & \\
\hline CONF3 & & & $.82(.65)$ & & & \\
\hline CONF1 & & & $.75(.71)$ & & & \\
\hline CONF2 & & & $.74(.61)$ & & & \\
\hline PRIC1 & & & & $.79(.63)$ & & \\
\hline PRIC3 & & & & $.76(.59)$ & & \\
\hline PRIC2 & & & & $.61(.63)$ & & \\
\hline DESI2 & & & & & $.76(.68)$ & \\
\hline DESI1 & & & & & $.75(.56)$ & \\
\hline DESI3 & & & & & $.75(.60)$ & \\
\hline BRAN1 & & & & & & $.87(.46)$ \\
\hline BRAN2 & & & & & & $.71(.79)$ \\
\hline \multicolumn{7}{|c|}{ Model fit index (CFA): } \\
\hline $\mathrm{CMIN}=$ & & & & & & \\
\hline
\end{tabular}

\subsection{Findings on relationship between time orientation and decision-making styles}

At the fundamental characteristic level, the results show that there are significant relationships between time orientation and fundamental characteristics of consumer's DMS.

For Present orientation, significant and positive relationships were shown between this time orientation and three out of six DMS characteristics, including Guarantee Consciousness, Perfection/ Best quality Consciousness and Confusion.

Past Orientation was found to have a significant and positive relationship with two out of six DMS characteristics, namely Attractive Design Consciousness and Confusion.

Future orientation is significantly related to four out of six characteristics, including Guarantee Consciousness, Perfection/ Best quality Consciousness, Price Consciousness, and Attractive Design Consciousness. All relationships are positive. No significant relationship was found between future orientation and Confusion and Brand Consciousness.

At the DMS level, by segmenting customers using DMS's fundamental characteristics, the results show four distinct segments as follow (see Chart 1):

Segment 1: "Design Consciousness Customers".

This segment includes 127 customers (20\% of the sample), which show highest interest among the four segments in the design of products when deciding to purchase an audiovisual product. Customers in this segment also reveal highest level of confusion compared to customers in the other three segments while paying least attention to brand reputation.

Regarding time orientation, the customers in this segment appear to have similar and high score to all past, future and present orientation. 
Table 3. The correlation between time orientation and DMS characteristics

\begin{tabular}{lccccccc}
\hline & $\begin{array}{c}\text { Guarantee } \\
\text { Consciousne } \\
\mathrm{ss}\end{array}$ & $\begin{array}{c}\text { Perfection/ Best } \\
\text { quality } \\
\text { Consciousness }\end{array}$ & Confusion & $\begin{array}{c}\text { Price Advantage } \\
\text { Consciousness }\end{array}$ & $\begin{array}{c}\text { Design } \\
\text { Consciousness }\end{array}$ & $\begin{array}{c}\text { Brand Reputation } \\
\text { Consciousness }\end{array}$ \\
\hline Past & 0.037 & -0.092 & 0.273 & 0.085 & 0.099 & 0.045 \\
Orientation & $(\mathrm{NS})$ & $(\mathrm{NS})$ & $\mathrm{p}=0.000$ & $(\mathrm{NS})$ & $\mathrm{p}=0.019$ & 0.188 & $(\mathrm{NS})$ \\
Future & 0.170 & 0.167 & 0.087 & 0.105 & $\mathrm{p}=0.000$ & 0.019 \\
Orientation & $\mathrm{p}=0.001$ & $\mathrm{p}=0.001$ & $(\mathrm{NS})$ & 0.034 & 0.070 & 0.038 \\
Present & 0.126 & 0.111 & 0.159 & $\mathrm{n}$ (NS) & $(\mathrm{NS})$ & $(\mathrm{NS})$ \\
Orientation & $\mathrm{p}=0.009$ & $\mathrm{p}=0.022$ & $\mathrm{p}=0.001$ & & & \\
\hline
\end{tabular}

Segment 2: "Guarantee and Brand Consciousness Customers"

This segment contains 109 customers ( $25.7 \%$ of the sample), who show interests in the guarantee and creditability of the brand when deciding to purchase an audiovisual product. These customers reveal good ability in choosing and evaluating audiovisual products when buying them (as they have lowest score in confusion compared to the other three segments). The major characteristic of this segment is similar to the segment of "Reassured and luxury customers" in the research conducted in 2015 by Dao and Jallais [24].

In terms of time orientation, the segment 2 is the least oriented to the past compared to the other three segments. They also have average orientation to both present and future.

Segment 3: "Perfection Consciousness Customers"

This segment consists of 131 customers (30.9\% of the sample). The characteristic of this segment regarding DMS is the attempt to find a best product. This "best product" is revealed through a balance between good quality and reasonable price while not a good brand nor good guarantee service (since the scores in Brand Reputation Consciousness and Guarantee Consciousness are low). The DMS of this segment is in contrast with that of the second segment (Guarantee and Brand Consciousness Customers).

Regarding time orientation, customers in this segment show average orientation to all of the three perspectives of time, namely past, present and future.

Segment 4: "Relativist Customers"

This segment is composed of 56 customers (13.2\% of the sample). In terms of the DMS of this segment, the customers show little effort on finding a product with good quality. In addition, all of the other consciousness indexes (on brand, guarantee, price, design) are also average compared to other segments. These results show a "relativeness" in the way how the customers think and act. In Dao and Jallais (2015), a similar segment was also found and named as "Relativist Customers" [24].

Regarding time orientation, customers in this segment show high orientation to the past while low orientation to the present and future (lowest orientation compared to the other three segments). Accoring to prior studies, this segment has a "nostalgic" style, which is contrast to the first segment (Design Consciousness Customers).

From the above results, we can conclude that segments with different DMS also show different time orientation. To clarify these differences more explicitly, this study conducted an ONE-WAY ANOVA analysis to compare the mean score of time orientation of customers belonging to the above four segments. The results of this analysis are presented in Table 4.

The results of the One-Way ANOVA analysis show that:

As can be seen in Table 4, The Past Orientation is significantly and statistically different between segments: Customers from segments $1 \& 4$ express a significantly higher degree of past emphasis than customers from segment $2 \& 3$. The Future Orientation is significantly and statistically different between segments: customers from segment 1 \& 2 express a higher degree of past emphasis than customers from segment $3 \& 4$. For the Present Orientation, no significant difference has been found between segments. 
Chart 1. Description of Customer's Segments identified by clustering

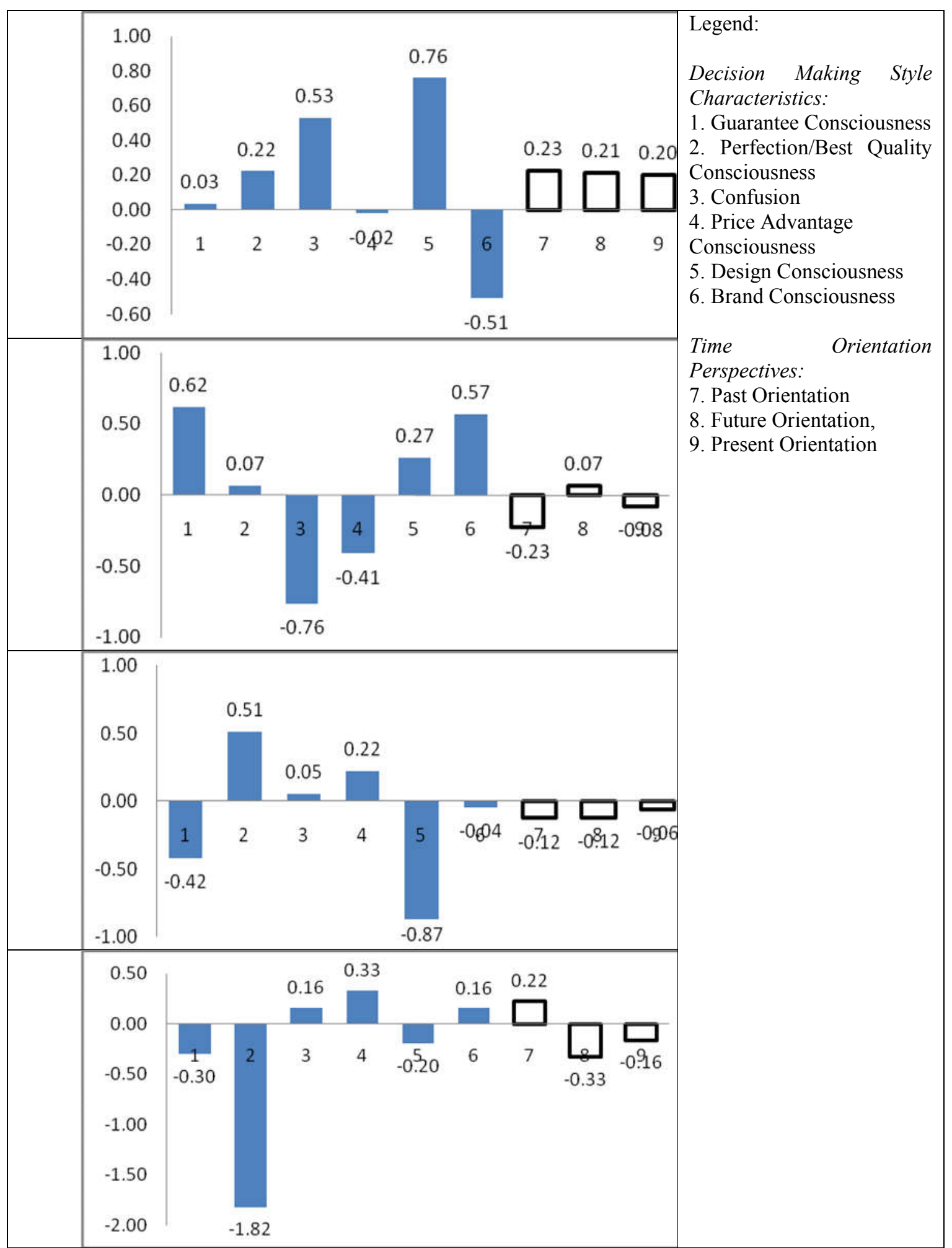


Table 4. Comparison of Time Orientation Mean Score among clusters (DMS)

\begin{tabular}{|c|c|c|c|c|c|}
\hline Criteria & Segment (i) & Segment (j) & $\begin{array}{r}\text { Mean difference } \\
(i)-(j)\end{array}$ & $\begin{array}{c}\text { Significance } \\
\text { level }\end{array}$ & Notes \\
\hline Past & 1 & 2 & 0.45 & 0.003 & Sig. \\
\hline \multirow[t]{5}{*}{ Orientation } & & 3 & 0.35 & 0.027 & Sig. \\
\hline & & 4 & 0.00 & 1.000 & n.s. \\
\hline & 2 & 3 & -0.10 & 1.000 & n.s. \\
\hline & & 4 & -0.45 & 0.034 & Sig. \\
\hline & 3 & 4 & -0.35 & 0.165 & n.s. \\
\hline Future & 1 & 2 & 0.15 & 1.000 & n.s. \\
\hline \multirow{5}{*}{ Orientation } & & 3 & 0.34 & 0.039 & Sig. \\
\hline & & 4 & 0.55 & 0.004 & Sig. \\
\hline & 2 & 3 & 0.02 & 0.851 & n.s. \\
\hline & & 4 & 0.40 & 0.088 & n.s. \\
\hline & 3 & 4 & 0.21 & 1.000 & n.s. \\
\hline Present & 1 & 2 & 0.28 & 0.180 & n.s. \\
\hline \multirow[t]{5}{*}{ Orientation } & & 3 & 0.26 & 0.202 & n.s. \\
\hline & & 4 & 0.37 & 0.130 & n.s. \\
\hline & 2 & 3 & -0.02 & 1.000 & n.s. \\
\hline & & 4 & 0.08 & 1.000 & n.s. \\
\hline & 3 & 4 & 0.10 & 1.000 & n.s. \\
\hline
\end{tabular}

\section{Conclusions and managerial implications}

With a survey of 423 customers, the results show that there are significant relationships between perspectives of time orientation (Past, Present, and Future Orientaion) and consumer's DMS in the context of audiovisual product purchasing at two levels: each characteristic and DMS (a specific combination of several characteristics). At the DMS's characteristics level, the results show that there are significant relationships between three perspectives of time orientation and six fundamental characteristics of DMS. Among perspectives of time orientation, the future orientation is found to have positive and significant relationships with 4 out of 6 DMS's characteristics. These results are similar to those from previous research on the impact of future orientation on consumer behavior $[10,11]$. Regarding customer's DMS, the research also reveals that the time orientation of customers is significantly different between four groups of customers formed by a clustering based on DMS's characteristics, except the present orientation. This means that each customer group, with a specific DMS, also has a specific time orientation pattern.
In terms of practical implications, marketing experts can apply customer's time orientation in segmenting the market. Moreover, the above results also allow marketing experts to understand deeper the psychological characteristics of customers and to base on that understanding to provide appropriate marketing strategies. For example, empirical results show that customers with strong past orientation tend to make mistakes in decisions of purchase and that their decisions are influenced highly by product design. Therefore, improving the design of products could facilitate the decision to buy from this type of customers. To customers who are strongly future-oriented, the main determinants of their decision to buy are good design and long-term guarantee. In addition, these customers also show a perfection-tendency in choosing a product and particularly care about the prices. Hence, the products should be designed or developed to satisfy these requirements from this segment of customers. Regarding present-oriented customers, their decisions to buy depend on the conditions and durations of guarantee. Besides, they also 
appear to search for "perfections" when deciding whether or not to buy a product.

Given the importance and siginificant practical implications of this topic, future research are strongly recommended to extend this topic in different research context or in different cultures and societies.

\section{References}

[1] Bergadaa, Michelle M., The Role of Time in the Action of the Consumer, Journal of Consumer Research, (17), 1990, 289-302.

[2] Tung DAO, An Empirical Investigation of the Relationship Between Temporal Orientation and Consumer Innovativeness in the Case of Purchase of A Durable Goods, Internationalization Studies, (1), 2014.

[3] Merchant A., Rose G., and Rose M., The Impact of Time Orientation on Consumer Innovativeness in the United States and India, Journal of Marketing Theory \& Practice, 22(4), 2012, 325-337.

[4] Karande, Kiran, and Altaf Merchant, The Impact of Time and Planning Orientation on an Individual's Recreational Shopper Identity and Shopping Behavior, Journal of Marketing, Theory and Practice, 20 (1), 2012, 59-72.

[5] Sproles, George B. and Kendall, Elizabeth L., A Methodology for Profiling Consumers' DecisionMaking Styles, The Journal of Consumer Affairs, 20(2), 1986, 267-279.

[6] Lewin, Kurt, Field Theory in Social Science: Selected Theoretical Papers, New York: Harper and Brothers, 1951.

[7] Zimbardo, Philip, Time to Take Our Time, Psychology Today, 35 (2), 2002, 62.

[8] Gonzalez, Alexander, and Philip G. Zimbardo, Time in Perspective: The Sense We Learn Early Affects How We Do Our Jobs and Enjoy Our Pleasures, Psychology Today, (19), 1985, 21-26.

[9] Hirsch A.R., Nostalgia: a neuropsychiatric understanding, Advances in Consumer Research, (19), 1992, 390-395.

[10] Agarwal A. and Tripathi K., Temporal orientation and deprivation, Journal of Psychological Research, (24), 1980, 144-152.

[11] Lens W. and Gaily A., Extension of future time perspective in motivational goals of different age groups, International Journal of Behavioral Development (3), 1980, 1-7.

[12] Davies G., What should time be? European Journal of Marketing, $28(8,9), 1993,100-113$.
[13] Zimbardo P., Foreword, in Psychology of Future Orientation of Zaleski Z., Towarzystwo Naukowe, Scientific Society of Kul, Lublin, Poland, 1994, 7-9.

[14] Sproles George B., From perfectionism to fadism: measuring Consumer's Decision Making Style, Proceedings, American Council on Consumer Interest, 1985, 79 - 85.

[15] Johnson R. H., Individual styles of decision-making: A theoretical Model for Counseling, The Personal and Guidance Journal, 56(9), 1978, 530-536.

[16] Heischmidt K. A. and Coscarelli W. C., Consumer attitudes important in choosing lawyers and accountants according to decision-making style, Journal of Professional Services Marketing, 12(2), 1995, 49-67.

[17] Edwards W., Utility theories: measurements and applications, Boston, MA: Kluwer Academic Publications, 1992.

[18] Keeney R. L. and Raiffa H., Decisions with multiple objectives: preferences and value tradeoffs, New York: Wiley, 1976.

[19] Jarboe G. R. and MCDANIEL C. D., A profile of browsers in regional shopping malls, Journal of the Academy of Marketing Science, 15(1), 1987, 46-53.

[20] Visser E. M. and Preez R., Apparel shopping orientation: Two decades of research, Journal of Family Ecology and Consumer Sciences, (29), 2001, 72-81.

[21] Sharma A. and Pillai R., Customers' decision making styles and their preference for sales strategies: Conceptual examination and an empirical study, Journal of Personal Selling et Sales Management, 16(1), 1996, 21-33.

[22] Uusitalo L., Identification of consumption style segments on the basis of household budget allocation, Advances in Consumer Research, (7), 1980, 451-459.

[23] Maloney S.K., Finn J., Bloom D.L. and Andresen J., Personal decision making styles and long-term care choice, Health Care Financing Review, 18(1), 1996, 141-155.

[24] Tung Dao and Joel Jallais, Investigation of Decisionmaking style of Vietnamese Consumers: the case of audiovisual goods purchases (in French), chapter in Book "China in the globalization", Editions: Editions Maison-Neuve \& Larose, France, 2005.

[25] Tung Dao, Time Style, Self-Efficacy, and Decisionmaking Style: Comparison between French and Vietnamese Consumers in the Purchase of Audiovisual Goods (in French), Presses Academiques Francophones, 2012, 520 pages.

[26] Said Ghezal, Assessing the Validity of a Small Business Strategy Instrument Using Confirmatory Factor Analysis, International Journal of the Academic Business World (9), 2015, 79-87. 


\section{Appendix}

Measurement Scale: Time Orientation

\begin{tabular}{|c|c|c|}
\hline No & Item & Code \\
\hline 1 & When I'm alone, I usually think about the past & PAST1 \\
\hline 2 & I like to think back and experience the days which already passed in my life & PAST2 \\
\hline 3 & I usually think about life (in general) in the past & PAST3 \\
\hline 4 & $\begin{array}{l}\text { I only focus on what I am doing at the present; other things are none of my } \\
\text { concerns. }\end{array}$ & PRES1 \\
\hline 5 & I think it's best to care about what is happening at the present. & PRES2 \\
\hline 6 & $\begin{array}{l}\text { To live with our best for the present is much more important than to plan for } \\
\text { the future. }\end{array}$ & PRES3 \\
\hline 7 & I think a lot about my life in the future & FUTU1 \\
\hline 8 & It's not my style to think and consider about the future* & FUTU2 \\
\hline 9 & I spend quite a lot of time to think about how I am going to be in the future & FUTU3 \\
\hline
\end{tabular}

(*) Item scores need to be reversed.

Measurement Scale: Fundamental Characteristics of Decision Making Styles

\begin{tabular}{|c|c|c|}
\hline No & Item & Code \\
\hline 1 & $\begin{array}{l}\text { Guarantee terms and conditions are the most important criteria to evaluate } \\
\text { the quality of the product }\end{array}$ & GUAR3 \\
\hline 2 & I choose to buy the product with the longest duration of guarantee. & GUAR2 \\
\hline 3 & The longer the product is guaranteed, the higher quality that product has. & GUAR1 \\
\hline 4 & $\begin{array}{l}\text { I am willing to pay more to extend the guarantee duration when I buy an } \\
\text { audiovisual product. }\end{array}$ & GUAR4 \\
\hline 5 & When buying an audiovisual product, I try to choose the best one. & PERF1 \\
\hline 6 & I try to buy an audiovisual product with best quality. & PERF2 \\
\hline 7 & To me, product quality is very important. & PERF3 \\
\hline 8 & $\begin{array}{l}\text { When buying an audiovisual product, I choose quickly and take the first } \\
\text { product (or brand) that I think is acceptable*. }\end{array}$ & PERF4 \\
\hline 9 & When there are many brands, I don't know what to choose. & CONF1 \\
\hline 10 & $\begin{array}{l}\text { All of the information that I have on competitive products makes me } \\
\text { confused in choosing a product for myself. }\end{array}$ & CONF2 \\
\hline 11 & $\begin{array}{l}\text { The more I know about compeititive brand, the harder it is for me to choose } \\
\text { a product to buy. }\end{array}$ & CONF3 \\
\hline 12 & Normally I choose a product with low price. & PRIC1 \\
\hline 13 & I usually buy audiovisual products when there is a sale or discount. & PRIC2 \\
\hline 14 & I am willing to spend time on finding a product with the best price. & PRIC3 \\
\hline 15 & $\begin{array}{l}\text { When there is a new product on the market, the first thing I pay attention to } \\
\text { is its design. }\end{array}$ & DESI1 \\
\hline 16 & $\begin{array}{l}\text { The design of the product is the first criteria that I take when comparing the } \\
\text { similar products from different brands or producers. }\end{array}$ & DESI2 \\
\hline 17 & Pretty design is very important to me. & DESI3 \\
\hline 18 & The more expensive the product is, the higher quality it has. & BRAN1 \\
\hline 19 & I usually choose the most expensive brand. & BRAN2 \\
\hline 20 & I will buy products from famous brands. & BRAN3 \\
\hline
\end{tabular}

(*) Item scores need to be reversed. 